Journal of Education and Teaching Learning (JETL)

Vol. 3, No. 1, 38-46 (2020)

Journal Homepage: http://pusdikra-publishing.com/index.php/jetl

\title{
UPAYA MENINGKATKAN PRESTASI BELAJAR PENDIDIKAN AGAMA ISLAM DENGAN MENERAPKAN MODEL PENGAJARAN KOLABORASI PADA SISWA KELAS VI SD NEGERI 101731 KP. LALANG KEC. SUNGGAL TAHUN PELAJARAN 2015/2016
}

\author{
Mardiyaini*)
}

\begin{abstract}
Abstrak
Desain penelitian ini menggunakan modifikasi penelitin tindakan kelas dalam 2 siklus terdiri dari perencanaan, pelaksanaan, pengamatan, dan refleksi. Subjek penelitian ini adalah Siswa Kelas VI SD Negeri 101731 Kp. Lalang Kec. Sunggal Yang berjumlah 33 siswa. Objek penelitian adalah meningkatkan prestasi belajar pendidikan agama islam dengan menerapkan model pengajaran kolaborasi pada siswa kelas Vi SD Negeri 101731 Kp. Lalang Kec. Sunggal tahun pelajaran 2015/2016. Hasil penelitian menunjukkan bahwa 1. Model pengajaran kolaborasi dapat meningkatkan kualitas pembelajaran PAI. 2. Pembelajaran model Kolaborasi memiliki dampak positif dalam meningkatkan prestasi belajar siswa yang ditandai dengan peningkatan ketuntasan belajar siswa dalam setiap siklus, yaitu siklus I (68,18\%), siklus II (79,01\%), siklus III (86,36\%). 3. Model pengajaran kolaborasi dapat menjadikan siswa merasa dirinya mendapat perhatian dan kesempatan untuk menyampaikan pendapat, gagasan, ide dan pertanyaan. 4. Siswa dapat bekerja secara mandiri maupun kelompok, serta mampu mempertanggungjawabkan segala tugas individu maupun kelompok. 5. Penerapan pembelajaran model Kolaborasi mempunyai pengaruh positif, yaitu dapat meningkatkan motivasi belajar siswa.
\end{abstract}

Kata kunci : Prestasi Belajar, Model Kolaborasi

\section{PENDAHULUAN}

Dalam kegiatan belajar mengajar yang berlangsung telah terjadi interaksi yang bertujuan. Guru dan anak didiklah yang menggerakannya. Interaksi yang bertujuan itu disebabkan gurulah yang memaknainya dengan menciptakan lingkungan yang bernilai edukatif demi kepentingan anak didik dalam belajar. Guru ingin memberikan layanan yang terbaik bagi anak didik, dengan menyediakan lingkungan yang menyenangkan dan menggairahkan. Guru berusaha menjadi pembimbing yang baik dengan peranan yang arif dan bijaksana, sehingga tercipta hubungan dua arah yang harmonis antara guru dengan anak didik.

\footnotetext{
*) Penulis adalah Guru SD Negeri 101731 Kp. Lalang Kec. Sunggal
} 
Ketika kegiatan belajar itu berproses, guru harus dengan ikhlas dalam bersikap dan berbuat, serta mau memahami anak didiknya dengan segala konsekuensinya. Semua kendala yang terjadi dan dapat menjadi penghambat jalannya proses belajar mengajar, baik yang berpangkal dari perilaku anak didik maupun yang bersumber dari luar anak didik, harus guru hilangkan, dan bukan membiarkannya. Karena keberhasilan belajar mengajar lebih banyak ditentukan oleh guru dalam mengelola kelas.

Dalam mengajar, guru harus pandai menggunakan pendekatan secara arif dan bijaksana, bukan sembarangan yang bisa merugikan anak didik. Pandangan guru terhadap anak didik akan menentukan sikap dan perbuatan. Setiap guru tidak selalu mempunyai pandangan yang sama dalam menilai anak didik. Hal ini akan mempengaruhi pendekatan yang guru ambil dalam pengajaran.

Guru yang memandang anak didik sebagai pribadi yang berbeda dengan anak didik lainnya akan berbeda dengan guru yang memandang anak didik sebagai makhluk yang sama dan tidak ada perbedaan dalam segala hal. Maka adalah penting meluruskan pandangan yang keliru dalam menilai anak didik. Sebaiknya guru memandang anak didik sebagai individu dengan segala perbedaannya, sehingga mudah melakukan pendekatan dalam pengajaran.

Kualitas pembelajaran ditentukan oleh interaksi komponen-komponen dalam sistemnya. Yaitu tujuan, bahan ajar (materi), anak didik, sarana, media, metode, partisipasi masyarakat, performance sekolah, dan evaluasi pembelajaran (Moh, Shochib, 1998). Optimalisasi komponen ini, menentukan kualitas (proses dan produk) pembelajaran. Upaya yang dapat dilakukan oleh pendidik adalah melakukan analisis tentang karakteristik setiap komponen dan mensinkronisasikan sehingga ditemukan konsistensi dan keserasian di antaranya untuk tercapainya tujuan pembelajaran. Karena pembelajaran mulai dari perencana, pelaksanaan dan evaluasinya senantiasa merujuk pada tujuan yang diharapkan untuk dikuasai atau dimiliki oleh anak didik baik instructional effect (sesuai dengan tujuan yang dirancang) maupun nurturrant effect (dampak pengiring) (Moch. Shochib: 1999).

Realisasi pencapaian tujuan tersebut, terdapat kegiatan interaksi belajar mengajar terutama yang terjadi di kelas. Dengan demikian, kegiatannya adalah bagaimana terjadi hubungan antara guru/bahan ajar yang didesain dan dengan anak didik. Interaksi ini 
merupakan proses komunikasi penyampaian pesan pembelajaran. Hal ini sejalan dengan yang dikemukakan Arief S Sadiman yang menyatakan proses belajar mengajar pada hakekatnya adalah proses interaksi yaitu proses penyampaian pesan melalui saluran media/teknik/ metode ke penerima pesan. (Arief S, Sadiman, dkk, 1996:13).

Sejalan dengan inovasi pembelajaran akhir-akhir ini termasuk di Sekolah Dasar, yaitu: Kolaborasi. Interaksi belajar mengajarnya menuntut anak didik untuk aktif, kreatif dan senang yang melibatkan secara optimal mental dan fisik mereka. Tingkat keaktifan, kreatifitas, dan kesenangan mereka dalam belajar merupakan rentangan kontinum dari yang paling rendah sampai yang paling tinggi. Tetapi idealnya pada kontinum yang tertinggi baik pelibatan aspek mental maupun fisik anak didik. Oleh karena itu, interaksi belajar mengajar dengan paradigma Kolaborasi menuntut anak:

(1) Berbuat

(2) Terlibat dalam kegiatan

(3) Mengamati secara visual

(4) Mencerap informasi secara verbal

Dengan demikian, interaksi belajar mengajar idealnya mampu membelajarkan anak didik berdasarkan problem based learning, authentic instruction, inquiry based learning, project based learning, service learning, and cooperative learning. Pola interaksi yang mampu mengemas hal tersebut dapat mengubah paradigma pembelajaran aktif menjadi paradigma pembelajaran reflektif.

Dengan interaksi pembelajaran reflektif dapat membuat anak didik untuk menjadikan hasil belajar sebagai referensi refleksi kritis tentang dampak ilmu pengetahuan dan teknologi terhadap masyarakat; mengasah kepedulian sosial, mengasah hati nurani, dan bertanggungjawab terhadap karirnya kelak. Kemampuan ini dimiliki anak didik, karena dengan pola interaksi pembelajaran tersebut, dapat membuat anak didik aktif dalam berfikir (mind-on), aktif dalam berbuat (hand-on), mengembangkan kemampuan bertanya, mengembangkan kemampuan berkomunikasi, dan membudayakan untuk memecahkan permasalahan baik secara personal maupun sosial.

Agar hasil ini dapat optimal, guru dituntut untuk mengubah peran dan fungsinya menjadi fasilitator, mediator, mitra belajar anak didik, dan evaluator. Ini berarti, guru harus menciptakan interaksi pembelajaran yang demokratis dan dialogis antara guru dengan 
anak didik, dan anak didik dengan anak didik (Moh. Shochib: 1999; dan Paul Suparno dkk: 2001).

Dengan interaksi pembelajaran yang mengemas nilai-nilai tersebut dapat membuat pembelajaran lingking (link and math atau life skill) dan delinking (pemutusan lingkungan negatif), diversifikasi kurikulum, pembelajaran kontekstual, kurikulum berbasis kompetensi, dan otonomi pendidikan pada tingkat sekolah taman kanak-kanak dengan manajemen berbasis sekolah, dan bertujuan untuk mengupayakan fondasi dan mengembangkan anak untuk memiliki kemampuan yang utuh yang disebut: Pendidikan Anak Seutuhnya (PAS).

Pada dasarnya dalam kehidupan suatu bangsa, faktor pendidikan mempunyai peranan yang sangat penting untuk menjamin perkembangan dan kelangsungan hidup bangsa tersebut. Secara langsung maupun tidak langsung pendidikan adalah suatu usaha sadar dalam menyiapkan pertumbuhan dan perkembangan anak melalui kegiatan, bimbingan, pengajaran dan pelatihan bagi kehidupan dimasa yang akan datang. Tentunya hal ini merupakan tanggung jawab bersama antara pemerintah, anggota masyarakat dan orang tua. Untuk mencapai keberhasilan ini perlu dukungan dan partisipasi aktif yang bersifat terus menerus dari semua pihak.

Guru mengemban tugas yang berat untuk tercapainya tujuan pendidikan nasional yaitu meningkatkan kualitas manusia Indonesia, manusia seutuhnya yang beriman dan bertakwa terhadap Tuhan Yang Maha Esa, berbudi pekerti luhur, berkepribadian, berdisiplin, bekerja keras, tangguh, bertanggung jawab, mandiri, cerdas dan terampil serta sehat jasmani dan rohani, juga harus mampu menumbuhkan dan memperdalam rasa cinta terhadap tanah air, mempertebal semangat kebangsaan dan rasa kesetiakawanan sosial. Sejalan dengan itu pendidikan nasional akan mampu mewujudkan manusia-manusia pembangunan dan membangun dirinya sendiri serta bertanggung jawab atas pembangunan bangsa. Depdikbud (1999).

Berhasilnya tujuan pembelajaran ditentukan oleh banyak faktor diantaranya adalah faktor guru dalam melaksanakan proses belajar mengajar, karena guru secara langsung dapat mempengaruhi, membina dan meningkatkan kecerdasan serta keterampilan siswa. Untuk mengatasi permasalahan di atas dan guna mencapai tujuan pendidikan secara maksimal, peran guru sangat penting dan diharapkan guru mampu 
menyampaikan semua mata pelajaran yang tercantum dalam proses pembelajaran secara tepat dan sesuai dengan konsep-konsep mata pelajaran yang akan disampaikan.

Dengan menyadari kenyataan tersebut di atas, maka dalam penelitian ini penulis mengambil judul "Upaya Meningkatkan Prestasi Belajar Pendidikan Agama Islam Dengan Menerapkan Model Pengajaran Kolaborasi Pada Siswa Kelas VI SD Negeri 101731 Kp. Lalang Kec. Sunggal Tahun Pelajaran 2015/2016."

\section{METODE PENELITIAN}

Penelitian ini merupakan penelitian tindakan (action research), karena penelitian dilakukan untuk memecahkan masalah pembelajaran di kelas. Penelitian ini juga termasuk penelitian deskriptif, sebab menggambarkan bagaimana suatu teknik pembelajaran diterapkan dan bagaimana hasil yang diinginkan dapat dicapai.

Tempat penelitian adalah tempat yang digunakan dalam melakukan penelitian untuk memperoleh data yang diinginkan. Penelitian ini bertempat di SD Negeri $101731 \mathrm{Kp}$. Lalang Kec. Sunggal, Kecamatan Porsea, Kabupaten Toba Samosir. Waktu penelitian adalah waktu berlangsungnya penelitian atau saat penelitian ini dilangsungkan. Penelitian ini dilaksanakan pada bulan Septemnre semester ganjil Tahun Pelajaran 2015/2016.

Subyek penelitian adalah siswa-siswi Kelas VI SD Negeri $101731 \mathrm{Kp}$. Lalang Kec. Sunggal Tahun Pelajaran 2015/2016 pada pokok bahasan kisah nabi lbrahim a.s, dan nabi Ismail a.s.

Sesuai dengan jenis penelitian yang dipilih, yaitu penelitian tindakan, maka penelitian ini menggunakan model penelitian tindakan dari Kemmis dan Taggart (dalam Arikunto, Suharsimi, 2002:83), yaitu berbentuk spiral dari siklus yang satu ke siklus yang berikutnya. Setiap siklus meliputi planning (rencana), action (tindakan), observation (pengamatan), dan reflection (refleksi).

\section{HASIL PENELITIAN DAN PEMBAHASAN}

A. Hubungan Pembelajaran Model Kolaborasi dengan Ketuntasan Belajar

1. Siklus I 
Pada akhir proses belajar mengajar siswa diberi tes formatif I dengan tujuan untuk mengetahui tingkat keberhasilan siswa dalam proses belajar mengajar yang telah dilakukan. Adapun data hasil penelitian pada siklus I adalah sebagai berikut.

Tabel 4.1. Rekapitulasi Hasil Tes Formatif Siswa Pada Siklus I

\begin{tabular}{|c|l|c|}
\hline No & \multicolumn{1}{|c|}{ Uraian } & Hasil Siklus I \\
\hline 1 & Nilai rata-rata tes formatif & 70,00 \\
2 & Jumlah siswa yang tuntas belajar & 15 \\
3 & Persentase ketuntasan belajar & 68,18 \\
\hline
\end{tabular}

Refleksi

Dalam pelaksanaan kegiatan belajar mengajar diperoleh informasi dari hasil pengamatan sebagai berikut:

1. Guru kurang maksimal dalam memotivasi siswa dan dalam menyampaikan tujuan pembelajaran

2. Guru kurang maksimal dalam pengelolaan waktu

3. Siswa kurang aktif selama pembelajaran berlangsung

2. Siklus II

Pada akhir proses belajar mengajar siswa diberi tes formatif II dengan tujuan untuk mengetahui tingkat keberhasilan siswa dalam proses belajar mengajar yang telah dilakukan. Instrumen yang digunakan adalah tes formatif II. Adapun data hasil penelitian pada siklus II adalah sebagai berikut.

Tabel 4.2. Rekapitulasi Hasil Tes Formatif Siswa Pada Siklus II

\begin{tabular}{|c|l|c|}
\hline No & \multicolumn{1}{|c|}{ Uraian } & Hasil Siklus II \\
\hline 1 & Nilai rata-rata tes formatif & 77,73 \\
2 & Jumlah siswa yang tuntas belajar & 17 \\
3 & Persentase ketuntasan belajar & 79,01 \\
\hline
\end{tabular}

Refleksi

Dalam pelaksanaan kegiatan belajar diperoleh informasi dari hasil pengamatan sebagai berikut.

1. Memotivasi siswa

2. Membimbing siswa merumuskan kesimpulan/menemukan konsep

3. Pengelolaan waktu

3. Siklus III 
Pada akhir proses belajar mengajar siswa diberi tes formatif III dengan tujuan untuk mengetahui tingkat keberhasilan siswa dalam proses belajar mengajar yang telah dilakukan. Instrumen yang digunakan adalah tes formatif III. Adapun data hasil penelitian pada siklus III adalah sebagai berikut.

Tabel 4.3. Hasil Formatif Siswa Pada Siklus III

\begin{tabular}{|c|l|c|}
\hline No & \multicolumn{1}{|c|}{ Uraian } & Hasil Siklus III \\
\hline 1 & Nilai rata-rata tes formatif & 82,73 \\
2 & Jumlah siswa yang tuntas belajar & 19 \\
3 & Persentase ketuntasan belajar & 86,36 \\
\hline
\end{tabular}

Refleksi

Pada tahap ini akan dikaji apa yang telah terlaksana dengan baik maupun yang masih kurang baik dalam proses belajar mengajar dengan penerapan pembelajaran model Kolaborasi. Dari data-data yang telah diperoleh dapat diuraikan sebagai berikut:

1. Selama proses belajar mengajar guru telah melaksanakan semua pembelajaran dengan baik. Meskipun ada beberapa aspek yang belum sempurna, tetapi persentase pelaksanaannya untuk masing-masing aspek cukup besar.

2. Berdasarkan data hasil pengamatan diketahui bahwa siswa aktif selama proses belajar berlangsung.

3. Kekurangan pada siklus-siklus sebelumnya sudah mengalami perbaikan dan peningkatan sehingga menjadi lebih baik.

4. Hasil belajar siswa pada siklus III mencapai ketuntasan.

\section{B. Pembahasan}

\section{Ketuntasan Hasil Belajar Siswa}

Melalui hasil penelitian ini menunjukkan bahwa pembelajaran model Kolaborasi memiliki dampak positif dalam meningkatkan prestasi belajar siswa. Hal ini dapat dilihat dari semakin mantapnya pemahaman siswa terhadap materi yang disampaikan guru (ketuntasan belajar meningkat dari siklus I, II, dan III) yaitu masing-masing 68,18\%, $79,01 \%$, dan $86,36 \%$. Pada siklus III ketuntasan belajar siswa secara klasikal telah tercapai. 


\section{Kemampuan Guru dalam Mengelola Pembelajaran}

Berdasarkan analisis data, diperoleh aktivitas siswa dalam proses belajar mengajar dengan menerapkan model pengajaran kolaborasi dalam setiap siklus mengalami peningkatan. Hal ini berdampak positif terhadap prestasi belajar siswa yaitu dapat ditunjukkan dengan meningkatnya nilai rata-rata siswa pad setiap siklus yang terus mengalami peningkatan.

\section{Aktivitas Siswa Dalam Pembelajaran}

Berdasarkan analisis data, diperoleh aktivitas siswa dalam proses pembelajaran PAI pada pokok bahasan kisah nabi Ibrahim a.s, dan nabi Ismail a.s dengan model pengajaran kolaborasi yang paling dominan adalah, mendengarkan/memperhatikan penjelasan guru, dan diskusi antar siswa/antara siswa dengan guru. Jadi dapat dikatakan bahwa aktivitas siswa dapat dikategorikan aktif.

Sedangkan untuk aktivitas guru selama pembelajaran telah melaksanakan langkah-langkah kegiatan belajar mengajar dengan menerapkan pengajaran konstekstual model pengajaran berbasis masalah dengan baik. Hal ini terlihat dari aktivitas guru yang muncul di antaranya aktivitas membimbing dan mengamati siswa dalam menemukan konsep, menjelaskan materi yang sulit, memberi umpan balik/evaluasi/tanya jawab dimana prosentase untuk aktivitas di atas cukup besar.

\section{SIMPULAN}

Berdasarkan hasil penelitian yang telah dipaparkan selama tiga siklus, hasil seluruh pembahasan serta analisis yang telah dilakukan dapat disimpulkan sebagai berikut:

1. Model pengajaran kolaborasi dapat meningkatkan kualitas pembelajaran PAI.

2. Pembelajaran model Kolaborasi memiliki dampak positif dalam meningkatkan prestasi belajar siswa yang ditandai dengan peningkatan ketuntasan belajar siswa dalam setiap siklus, yaitu siklus I (68,18\%), siklus II (79,01\%), siklus III (86,36\%).

3. Model pengajaran kolaborasi dapat menjadikan siswa merasa dirinya mendapat perhatian dan kesempatan untuk menyampaikan pendapat, gagasan, ide dan pertanyaan. 
4. Siswa dapat bekerja secara mandiri maupun kelompok, serta mampu mempertanggungjawabkan segala tugas individu maupun kelompok.

5. Penerapan pembelajaran model Kolaborasi mempunyai pengaruh positif, yaitu dapat meningkatkan motivasi belajar siswa.

\section{DAFTAR PUSTAKA}

Arikunto, Suharsimi. 2002. Prosedur Penelitian Suatu Pendekatan Praktek. Jakarta: Rineksa Cipta.

Djamarah, Syaiful Bahri. 2002. Strategi Belajar Mengajar. Jakarta: Rineksa Cipta.

Hamalik, Oemar. 2002. Psikologi Belajar dan Mengajar. Bandung: Sinar Baru Algesindo.

Hasibuan K.K. dan Moerdjiono. 1998. Proses Belajar Mengajar. Bandung: Remaja Rosdakarya.

Margono. 1997. Metodologi Penelitian Pendidikan. Jakarta. Rineksa Cipta.

Masriyah. 1999. Analisis Butir Tes. Surabaya: Universitas Press.

Ngalim, Purwanto M. 1990. Psikologi Pendidikan. Bandung: PT. Remaja Rosdakarya.

Soekamto, Toeti. 1997. Teori Belajar dan Model Pembelajaran. Jakarta: PAU-PPAI, Universitas Terbuka.

Syah, Muhibbin. 1995. Psikologi Pendidikan, Suatu Pendekatan Baru. Bandung: Remaja Rosdakarya.

Usman, Moh. Uzer. 2001. Menjadi Guru Profesional. Bandung: Remaja Rosdakarya. 